\title{
APLIKASI TEKNOLOGI PENDIDIKAN \\ DI ERA GLOBAL
}

\author{
Husni Idris*
}

\begin{abstract}
Abstrak
Teknologi Pendidikan tumbuh dari praktek pendidikan dan gerakan komunikasi audio visual. Teknologi Pembelajaran semula dilihat sebagai teknologi peralatan, yang berkaitan dengan penggunaan peralatan, media dan sarana untuk mencapai tujuan pendidikan atau dengan kata lain mengajar dengan alat bantu audio-visual dan dengan pengembangan aplikasi dari teknologi internet. Saat ini, ketergantungan dunia pendidkan pada teknologi internet dalam pendidikan (baca: teknologi pendidikan) sangatlah besar, hal ini dapat dilihat banyaknya aplikasi-aplikasi yang diteapakan dalam pembelajaran. Bahkan apalikasi-aplikasi yang digunakan orang secara bias juga dijadikan media dalam pembelajaran, dan hal ini tentu saja tidak lepas dari peran teknologi pendidikan itu sendiri. Dalam tulisan akan dibahas, beberapa aplikasi internet yang digunakan dalam pendidikan dan pembelajaran dan beberapa issue seputar teknologi pendidikan.
\end{abstract}

Kata Kunci: Teknologi pendidikan, Aplikasi Internet, Globalisasi

\section{Pendahuluan}

Kata global menunjuk kepada sesuatu yang berkaitan dengan dunia secara keseluruhan termasuk di dalamnya isi dunia. Dari pengertian singkat ini, kiranya terdapat skop kajian yang sangat padat. Sehubungan dengan iu, dalam uraian makalah ini perlu didiskusikan pembahasannya.

Globalisasi melahirkan masyarakat yang terbuka. Masyarakat tersebut merupakan konsekuensi dari masyarakat yang memberikan nilai kepada individu, kepada hak dan kewajiban sehingga semuanya mempunyai kesempatan yang sama untuk mengembangkan potensinya dan kemampuan bagi kepentingan bersama.

Menurut Hamijaya, menyebutkan ciri-ciri yang berkaitan dengan globalisasi yakni:

*Penulis dosen tetap pada Jurusan Tarbiyah STAIN Manado. 
1. Globalisasi perlu didukung oleh kecepatan informasi, kecanggihan teknologi, transportasi dan komunikasi yang diperkuat oleh tatanan organasasi dan manajemen yang tangguh.

2. Globalisasi telah melampaui batas geo-politik. Batas tersebut saat ini harus tunduk pada kekuatan teknologi, ekonomi, sosial politik dan sekaligus mempertemukan tatanan yang sebelumnya sulit dipertemukan.

3. Adanya unsur saling ketergantungan.

4. Pendidikan merupakan bagian dari globalisasi. Penyebaran dalam hal gagasan pembaharuan, inovasi dalam struktur, isi dan metode pendidikan dan pengajaran sudah lama terjadi. ${ }^{1}$

Pengaruh globalisasi juga semakin terasa berkat banyaknya saluran informasi dalam berbagai bentuk media baik cetak maupun elektronik seperti suratkabar, majalah, radio, TV, telepon, komputer, satelit komunikasi dsb. Informasi juga makin banyak tersedia dimana-mana dengan mudah dan murah, bahkan tanpa kita kehendaki telah menyerbu kita, anak-anak dan keluarga kita.

Semula globalisasi dipahami dengan keyakinan sepenuhnya akan mampu menuntun pada terjadinya perkembangan ekonomi dalam skala pasar yang lebih besar, yang akan mendorong meningkatnya pendapatan rata-rata, dimana negara miskin atau dunia ketiga akan bisa berkembang dengan lebih cepat, sehingga diharapakan kesenjangan ekonomi antara negara kaya dan negara di dunia ketiga akan menjadi semkin kecil. Tetapi kenyataan menunjukkan hal yang jauh berbeda. Pendapatan rata-rata memang meningkat, namun kesenjangan pendapatan anatara kedua negara itu juga bertambah besar.

Pada saat kita disibukkan dengan pengaruh globalisasi yang hampir "menjajah" seluruh kehidupan mannusia, pada saat yang sama kita juga memasuki era informasi. Teknologi komunikasi dan informasi yang harus berkembang telah dan cenderung akan terus mempengaruhi segenap kehidupan manusia. Perangkat keras komunikasi kita lihat kecil dan kompak dengan kemampuannya mengumpulkan, menyimpan, mengolah dan menyajikan informasi makin besar menembus batas-batas geografis, politis maupun

\footnotetext{
${ }^{1}$ Nursid Sumaatmadja, Persepektif Global. (Jakarta: Universitas Terbuka, 1999), h. 1-6.
} 
kedaulatan. Sementara biaya yang diperlukan untuk memperoleh informasi, terutama biaya transmisi data secara cepat dalam jarak jauh cenderung makiun murah, produk teknologi informasi (perangkat keras maupun lunak) makin mudah dan akrab penggunannya.

\section{Aplikasi Teknologi dalam Pendidikan}

Teknologi terus berkembang dari waktu ke waktu dalam segi jumlah, tingkat kerumitan, dan kemampuannya. Media pendidikan sebagai produk dari teknologi pun kita lihat semakin bervariasi mulai dari yang sederhana hingga yang canggih. Media cetak dan non-cetak, elektronik dan non-elektronik, proyeksi maupun non-proyeksi pada dasarnya memiliki potensi untuk menunjang kegiatan pendidikan dan pembelajaran. Apapun juga teknologi dan media yang digunakan adalah yang penting adalah interaksi dua arah antara peserta didik dan pendidiknya. Pemilihan teknologi dan jenis interaksi pembelajaran yang akan digunakan tergantung pada kebutuhan lembaga penyelenggara pendidikan dan pelatihan yang bersangkutan. Tidak ada teknologi yang paling bagus untuk mencapai semua tujuan, mengingat keunggulan dan keterbatasan masing-masing teknologi pemilihan dan penggunaannya dalam pendidikan haruslah bersifat pragmatis karena teknologi cepat sekali berkembang. Berbagai pilihan teknologi mulai dari yang sederhana ke yang canggih dan mutakhir dikelompokkan oleh Chute sebagai mana dikutip, yakni:

a. Teknologi Audio. Pilihan teknologi interaktif yang sederhana adalah telepon. Sebagai media komunikasi telepon dapat dimanfaatkan untuk tujuan pendidikan dan belajar. Pada awalnya memang aneh belajar lewat telepon namun lama kelamaan cara baru ini, baik perorangan maupun kelompok lewat konferensi audio mulai bermasyarakat, apalagi dengan semakin berkembangnya telepon yang mudah dibawa-bawa (baca: handphone, red), yang didukung dengan fasilitas seperti SMS, MMS dan EMS.

b. Teknologi Audio dan Data. Perpaduan kemampuan audio dari telepon dan kemampuan data komputer telah melahirkan apalikasi belajar jarak jauh yang disebut audiografis. Di sini telepon digunakan untuk interaksi dua arah sedangkan komputer digunakan untuk berbagai bahan grafis dan memungkinkan dilaksanakannya kerja bersama diantara para peserta didik. 
c. Teknologi Video. Teknologi yang masuk dalam kategori ini adalah kaset video, siaran video satu arah, video on demand, video dan CBT, dan video dua arah.

d. Computer Based Training. Ini bentuk lain dari aplikasi teknologi untuk pendidikan yang menggunakan komputer. Bentuknya bisa Computer Assisted Intruction (CAI) atau Computer Managed Instruction (CMI).

e. Computer Coonferencing. Ini adalah istilah umum yang digunakan untuk memayungi berbagai penerapan teknologi komputer yang menunjang komunikasi antar manusia. Yang paling lazim dalam kelompok ini adalah surat elektronik (e-mail), system konperensi kelompok (group conferencing system) dan system penyampaian pesan interaktif (interactive messaging system).

f. Pendidikan dan Pelatihan di Internet. Dalam situasi yang seperti sekarang ini, diperlukan tersedianya sumber-sumber belajar yang actual, kaya dan mudah dijangkau. Internet adalah teknologi yang memberikan landasan kuat bagi penciptaan lingkungan belajar yang kaya dan luwes serta mampu memenuhi pendidikan dan latihan. $^{2}$

Internet merupakan jaringan global yang menghubungkan beribu bahkan berjuta jaringan komputer (local/wide areal network) dan komputer pribadi (stand alone), yang memungkinkan setiap komputer yang terhubung bisa melakukan komunikasi satu sama lain. Jaringan ini bukan merupakan suatu organisasi atau institusi, karena tidak satu pihak pun yang mengatur dan memilikinya. ${ }^{3}$

Fasilitas aplikasi internet sangatlah beragam sehingga mampu memberikan dukungan bagi militer ${ }^{4}$, kalangan akademisi, kalangan media massa, maupun kalangan bisnis. Fasilitas seperti Telnet, Gopher, WAIS, e-mail, Mailing List (milis), Newsgroup, File Transfer Protocol (FTP), Internet Relay Chat, World Wide Web (WWW). Diantara

${ }^{2}$ Arief S. Sadiman, Aplikasi Teknologi dalam Pendidikan di Era Global (Makalah; 2003), h. 6.

${ }^{3}$ Hariana Yuhetty dan Hardjito, Edukasi Net Pembelajaran Berbasis Internet: Tantangan dan Peluang (Makalah; 2004), h. 9.

${ }^{4}$ Awalnya internet lahir untuk suatu keperluan militer Amerika Serikat. Pada awal tahun 1969 Avanced Research Project Agency (ARPA) dari Departemen Pertahana AS, membuat eksperimen jaringan yang diberi nama ARPAnet untuk mendukung keperluan penelitian (riset) kalangan militer. Tetapi dalam perkembangan selanjutnya jaringan ini dipergunakan untuk keperluan perguruan tinggi, yang dimulai dengan University of California, Standford Research Institute dan University of Utah. 
fasilitas yang ada tersebut lima aplikasi standar internet yang dapat dipergunakan untuk keperluan pendidikan, yaitu E-mail, Mailing List (milis), Newsgroup, File Transfer Protocol (FTP), World Wide Web (WWW).

Dari sejumlah studi yang telah dilakukan, menunjukkan bahwa internet memang bisa dipergunakan sebagai media pembelajaran, seperti studi telah dilakukan oleh Center for Applied Special Technology (CAST) tahun 1996, yang dilakukan terhadap sekitar 500 murid kelas lima dan enam SD. Ke 500 murid tersebut dimasukkan ke dalam dua kelompok yaitu, kelompok eksperimen yang dalam kegiatan belajarnya dilengkapi dengan akses internet dan kelompok terkontrol. Setelah dua bulan menunjukkan bahwa kelompok eksperimen mendapat nilai yang lebih tinggi berdasarkan hasil tes akhir.

Begitu juga dengan studi eksperimen mengenai penggunaan internet untuk mendukung kegiatan belajar mengajar Bahasa Inggris yang dilakukan oleh Anne L. Rantie dan kawan-kawan di SMU 1 BPK Penabur Jakarta tahun 1999, menunjukkan bahwa murid yang terlibat eksperimen tersebut memperlihatkan peningkatan kemampuan mereka secara signifikan dalam menulis dan membuat karangan dalam bahasa Inggris. ${ }^{5}$

Dengan demikian, terlihat bahwa sebagaimana media lain yang selama ini telah dipergunakan sebagai media pendidikan secara luas, internet juga mempunyai peluang yang tak kalah besarnya dan bahkan mungkin karena karateristiknya yang khas suatu saat nanti internet bisa menjadi media pembelajaran yang paling terkemuka dan paling dipergunakan secara luas.

\section{Pengunaan Untuk Pendidikan dan Pembelajaran}

Pendayagunaan internet untuk pendidikan dan pembelajaran bisa dilakukan dalam tiga bentuk (Haughey, 1998), yaitu (1) Web Course, (2) Web Centric, dan (3) Web Enhancsed Course.

Web Course, ialah penggunaan internet untuk keperluan pembelajaran, dimana seluruh bahan belajar, diskusi, konsultasi, penugasan, latihan dan ujian sepenuhnya disampaikan melelui internet. Siswa dan guru sepenuhnya terpisah, namun hubungan atau komunikasi antara peserta didik dengan pengajar bisa dilakukan setiap saat.

\footnotetext{
${ }^{5}$ Hariana Yuhetty dan Hardjito, op cit., h. 12.
} 
Web Centric Course, dimana sebagian bahan belajar, diskusi, konsultasi, penugasan dan latihan disampaikan melalui internet, sedangkan ujian dan sebagian konsultasi, diskusi dan latihan dilakukan secara tatap muka. Walaupun dalam proses belajarnya sebagian dilakukan dengan tatap muka yang biasanya berupa tutorial, tetapi presentasi tatap muka tetap lebih kecil dibandingkan dengan persentase proses belajar melalui internet.

Web Enhnaced Course, yaitu pemanfaatan internet untuk pendidikan, untuk menunjang peningkatan kulaitas kegiatan belajar mengajar di kelas. Bentuk ini juga dikenal dengan nama Web lite course, karena kegiatan pembelajaran utamanya adalah tatap muka di kelas.

Peranan internet disini adalah untuk menyediakan content (sumber belajar) yang sangat kaya dan juga memberikan fasilitas hubungan (link) ke berbagai sumber belajar. Juga tak kalah pentingnya ialah pemberian fasilitas komunikasi antara pengajar dengan peserta didik secara timbal balik. Dialog atau komunikasi tersebut adalah untuk keperluan berdiskusi, berkonsultasi, maupun untuk bekerja secara kelompok (kolaborasi). Berbeda dengan kedua bentuk sebelumnya, pada bentuk Web Enchanced Course ini presentase pembelajaran melalui internet justru lebih sedikit dibandingkan dengan prresentase pembelajaran secara tatap muka, karena penggunaan internet adalah hanya untuk mendukung kegiatan pembelajaran secara tatap muka.

\section{Issue Teknologi}

Tidak perlu diragukan lagi kontribusi teknologi khususnya teknologi komunikasi dan informasi bagi pendidikan sangat besar. Namun ada baiknya kita berhati-hati dalam mendayagunakan teknologi untuk pendidikan. Beberapa issue berikut ini perlu kiranya kita perhatikan:

Teknologi tepat guna. Kata tepat guna (appropriate) adalah kunci keberhasilan pendayagunaan teknologi untuk memecahkan masalah pendidikan. Yang penting bukanlah seberapa canggih teknologi yang digunakan tetapi seberapa sesuaikah teknologi tersebut dengan kebutuhan, masalah dan kondisi kita. Teknologi tidak akan mendatangkan perbaikan dengan sendirinya namun sangat tergantung pada orang 
yang mengembangkan dan memanfaatkannya. Potensi teknologi hanya akan tinggal sebagai potensi apabila tidak didayagunakan dengan sengaja, terencana dan sistematis.

Kebudayaan. Teknologi adalah bagian dari kebudayaan tetapi tidak selalui sesuai satu sama lain. Seringkali ada pertentangan kepentingan. Teknologi bersifat amoral dan tidak memihak. Moralitas teknologi terletak pada bagaimana ia digunakan. Bukan perangkat keras yang menjadi masalah tetapi bagaimana program atau perangkat lunak dirancang dan disajikan lewat perangkat keras tersebut.

Teknologi dan Pemerataan. Ada kecenderungan teknologi memperlebar kesenjangan yang maju dan yang terbelakang, yang kaya dan yang miskin, kota dan desa. Teknologi seharusnya memeratakan kesempatan memperoleh pendidikan bermutu seluas-luasnnya.

Bahaya Salesman. Seringkalai teknologi mahal digunakan semata-mata karena diberi secara cuma-cuma oleh perusahaan besar atau dengan harga miring. Pemasar teknologi biasanya cenderung berbicara tentang kehebatan perangkat keras dan kurang memberikan perhatian pada konsep bahan belajar, strategi belajar-mengajar, masalah akses dan tenaga. Dalam banyak kasus seringkali teknologi yang menggiring arah pendidikan, bukannya kebutuhan atau permasalahan pendidikan yang ada.

> Over Expectation. Banyak orang berpikir bahwa teknologi adalah obat mujarab (panacea) yang dapat memecahkan semua masalah (pendidikan). Kita tidak boleh terlalu berharap karena teknologi tidak selamanya menjadi solusi yang dapat menjamin terlaksananya proses belajar yang baik. Teknologi hanyalah alat yang dapat memnunjang pendidikan dan pembelajaran.

Rate of Adoption. Adopsi teknologi merupakan masalah tersendiri. Pemanfaatan teknologi dalan pendidikan jarak jauh relative lebih cepat dan maju dibandingkan dengan pendidikan konvensional. Pendidikan dalan kenyataannya belum sepenuhnya menjawab kebutuhan (market driven) dan relative lamban mengadopsi teknologi. 
Berbeda dengan sector swasta, penerapan teknologi di pendidikan tidak dipandang sebagai masalah hidup mati tetapi lebih banyak sebagai symbol kemajuan.

DEfektivitas Biaya, juga merupakan issue yang sering dipersoalkan. Ini bisa dipahami karena pada dasarnya teknologi harus memenuhi prinsip efesiensi dan efektivitas.

Pendayagunaan teknologi dalam pendidikan tidak selamanya berjalan dengan mulus, baik dan lancar. Itu semua tergantung pada proses alih teknologi, baik yang bersifat hardware dan software. Transfer terakhir ini meyangkut alih know how, know why dan do how. Seringkali alih teknologi menimbulkan masalah lain. Kegagalan ini, sebagaimana dikemukakan Keating dan AECT kemungkinan disebabkan oleh hal-hal berikut:

* Tuntutan kebutuhan. Kurangnya tuntutan kebutuhan untuk memanfaatkan teknologi kemnungkinan akan menghambat atau memperlambat alih teknologi. Ada kalanya kegagalan disebabkan oleh kesalahan dalam menganalisis kebutuhan. Orang mengajukan pemecahan yang salah atas permasalahan yang benar. Teknologi memang lambang kemajuan. Dari waktu ke waktu kita melihat perkembangan teknologi yang baru, produk baru dengan kecanggihan yang baru pula. Seringkali terlupa alasan yang sebenarnya untuk menggunakan teknologi. Orang cenderung menggunakan teknologi karena situasi memungkinkannya untuk menggunakan bukan karena memang perlu untuk menggunakannya.

* Kurangnya kesungguhan dalam penerapan teknologi dalam bentuk dukungan kebijakan yang tegas dan jelas dalam pendayagunaan teknologi termasuk upaya penggalakan dan pemberian penghargaan akan menghambat proses alih teknologi.

Biaya yang kurang merupakan alasan klasik namun tetap relevan, telah banyak proyek pendayagunaan teknologi untuk pendidikan namun akhirnya terhenti karena kurangnya dana pendukung.

* Dukungan infrastruktur. Tanpa dukungan infrasturktur yang baik alih teknologi akan menjumpai masalah karena bagaimanapun juga teknologi sangat tergantung pada 
system yang ada. Alih teknologi komunikasi dan informasi juga menuntut adanya perubahan organisasi.

* Alih teknologi juga akan gagal karena orang terlalu memusatkan perhatian ke perangkat keras, bukannya ke sumber daya manusia yang akan menanganinya.

Kurang terkaitnya teknologi (terutama perangkat lunak) dengan tuntutan kurikulum juga merupakan penghambat tersendiri pendayagunaan teknologi dalam pendidikan.

Apapun juga teknologi komunikasi dan informasi yang akan kita gunakan dalam pendidikan agar dapat berfungsi dengan baik hendaknya kita perhatikan beberapa hal sebagaimana berikut:

$\checkmark$ Ketidakpuasaan akan status quo. Para pengelola pendidikan dan pembelajaran hendaknya merasakan tidak puas akan kondisi yang ada. Ketidakpuasaan ini merupakan pintu masuk ke penggunaan teknologi dalam pendidikan.

$\checkmark$ Siapapun juga yang terlibat dalam pemanfaatan teknologi komunikasi/informasi haruslah memiliki pengetahuan dan keterampilan yang diperlukan. Untuk itu perlu latihan dan pelatihan untuk terus menyesuaikan diri dan tuntutan jaman.

$\checkmark$ Dukungan sumber. Kecuali perangkat keras dan lunak masih diperlukan adanya dukungan sumber lain yang membantu pihak-pihak yang menggunakan teknologi komunikasi/informasi. Sektor produksi yang terus menyediakan suku cadang, perawatan dan perbaikan ikut menentukan keberhasilan ini.

$\checkmark$ Ganjaran dan hukuman dalam berbagai macam bentuknya perlu diberikan pada pihak-pihak yang terlibat dalam pendayagunaan teknologi untuk pendidikan.

$\checkmark$ Komitmen dan peran serta semua pihak yang terlibat, mulai dari tingkat yang teratas hingga ke bawah, baik pengelola maupun pengguna, untuk melaksanakan penggunaan teknologi komunikasi/informasi juga akan menentukan keberhasilan kita. 
$\checkmark$ Kepemimpinan. Kepedulian dan keterlibatan pimpinan lembaga pendidikan mulai dari yang teratas hingga ke bawah dalam pendayagunaan teknologi juga akan menentukan keberhasilan.

$\checkmark$ Perlu tersedia cukup waktu untuk memasyarakatkan pendayagunaan teknologi bukan saja untuk merencanakan tetapi juga belajar menggunakan dan mengintegrasikan dalam proses belajar mengajar.

\section{Kesimpulan}

Teknologi Internet yang pada awalnya diperuntukkan bagi kalangan militer, ternyata sesuai dengan perkembangan zaman sekarng justru lebih banyak digunakan dalam dunia pendidikan. Hal membuktikan bahwa internet di dunia pendidikan mempunyai peluang yang tak kalah besarnya dan bahkan mungkin karena karateristiknya yang khas suatu saat nanti bisa menjadi media pembelajaran yang paling terkemuka dan paling dipergunakan secara luas.

Satu hal yang perlu diperhatikan adalah, bagaimana pun majunya teknologi ada beberapa issue yang perlu diperhatikan agar para ahli, pemerhati, dan konsumen pendidikan tidak "terlena" dengan dunia maya ini. Seberapa canggih pun teknologi yang digunakan tetap harus disesuaikan dengan kebutuhan, masalah dan kondisi dimana kita berada. Teknologi tidak akan mendatangkan perbaikan dengan sendirinya namun sangat tergantung pada orang yang mengembangkan dan memanfaatkannya. Potensi teknologi hanya akan tinggal sebagai potensi apabila tidak didayagunakan dengan sengaja, terencana dan sistematis. 


\section{Daftar Pustaka}

AECT (1997), Educational technology: definition and glossary of terms, Vol. 1. Washington DC: AECT.

Budininsih, Asri., 2003. Kerangka Perkuliahan dan Bahan Pembelajaran (Dasar-Dasar Teknologi Pendidikan), Program Studi Teknologi Pendidikan Fakultas Ilmu Pendidikan UNY.

Kumpulan Makalah, 2005. Seminar Nasional Teknologi Pembelajaran (Hotel Inna Garuda Yogyakarta, 22-23 Agustus 2003), Program Studi Teknolog Pembelajaran PPS UNY.

Miarso, Yusuf Hadi, 2004. Menyemai Benih Teknologi Pendidikan. Jakarta: Fajar Interpratama Offset Kerja sama dengan Pustekkom Diknas.

Prawiradilaga, Dewi Salma dan Eveline Siregar, 2004. Mozaik Teknologi Pendidikan, Ed. 1, Cet. I, Kencana: Jakarta.

Sadiman, Arief S., 2003. Aplikasi Teknologi dalam Pendidikan di Era Global (Makalah).

Seels, Barbara B. dan Rita C. Richey, 1994. Teknologi Pembelajaran ; Definisi dan Kawasannya, diterj. Dewi S. Prawiradilaga, Raphael Rahardjo dan Yusuf hadi Miarso, Unit Percetakan Universitas Negeri Jakarta.

Sumaatmadja, Nursid. 1999. Persepektif Global. Jakarta: Universitas Terbuka.

Yuhetty, Hariana dan Hardjito, 2004. Edukasi Net Pembelajaran Berbasis Internet: Tantangan dan Peluang (Makalah). 